\title{
Playing dead to stay alive: death-feigning in Liolaemus occipitalis (Squamata: Liolaemidae)
}

\author{
Maurício Beux dos Santos ${ }^{1,3}$, Mauro Cesar Lamim Martins de Oliveira ${ }^{1}$, \\ Laura Verrastro ${ }^{2}$ \& Alexandro Marques Tozetti ${ }^{1}$ \\ ${ }^{1}$ Laboratório de Ecologia de Vertebrados Terrestres, Instituto de Ciências Biológicas, \\ Universidade Federal do Rio Grande - FURG, Av. Itália, Km 8, CEP 96201-900, Rio Grande, RS, Brazil \\ ${ }^{2}$ Laboratório de Herpetologia, Departamento de Zoologia, IB, Universidade Federal do Rio Grande do Sul, \\ Av. Bento Gonçalves, 9500, CEP 91501-970, Porto Alegre, RS, Brazil \\ ${ }^{3}$ Corresponding author: Maurício Beuxdos Santos, e-mail: mbeuxs@yahoo.com.br
}

SANTOS, M.B., OLIVEIRA, M.C.L.M., VERRASTRO, L. \& TOZETTI, A.M. Playing dead to stay alive: deathfeigning in Liolaemus occipitalis (Squamata: Liolaemidae). Biota Neotrop. 10(4): http://www.biotaneotropica. org.br/v10n4/en/abstract?short-communication+bn03110042010.

\begin{abstract}
Predation is the major selective force that drives the development of a series of defense mechanisms by the species. These mechanisms are efficient in that it limits the ability of predators to detect, recognize and subdue their prey. In lizards for example, the tail loss and locomotor escape are the most common defensive behavior reported on the literature. Additionally, in response to external stimuli, some lizards exhibit a peculiar defensive behavior: death-feigning or thanatosis. Here we describe the first record of death-feigning in a population of Liolaemus occipitalis in a coastal sand dune habitat in Southernmost Brazil. A total of 86 individuals were tested. During handling $75.6 \%$ of lizards feigned death. The duration of this behavior was longer when the observer remained closer to the lizards, suggesting the ability of $L$. occipitalis to evaluate the predation risk.
\end{abstract}

Keywords: thanatosis, behavior, sand-dune lizard, pampa, restinga.

SANTOS, M.B., OLIVEIRA, M.C.L.M., VERRASTRO, L. \& TOZETTI, A.M. Simulando a morte para manter-se vivo: tanatose em Liolaemus occipitalis (Squamata: Liolaemidae). Biota Neotrop. 10(4): http:// www.biotaneotropica.org.br/v10n4/pt/abstract?short-communication+bn03110042010.

Resumo: A pressão exercida pela predação é a principal força seletiva que direciona o estabelecimento de uma série de mecanismos de defesa por parte das espécies. Esses mecanismos são eficientes na medida em que limitam a capacidade dos predadores em detectar, reconhecer ou subjugar suas presas. Em lagartos, por exemplo, os comportamentos defensivos mais frequentemente citados na literatura são a autotomia caudal e a fuga. Além disso, em resposta a estímulos externos, alguns lagartos podem exibir um comportamento peculiar: fingem-se de mortos (tanatose). Neste estudo descrevemos o primeiro registro de tanatose em uma população de Liolaemus occipitalis em área de dunas costeiras no extremo Sul do Brasil. Um total de 86 indivíduos foram testados. Durante o manuseio, 75,6\% dos lagartos exibiram o comportamento de tanatose. A duração deste comportamento foi maior quando o observador permanecia a distâncias mais curtas dos lagartos, sugerindo uma capacidade de L. occipitalis em avaliar o risco de predação.

Palavras-chave: tanatose, comportamento, lagartixa-das-dunas, pampa, restinga. 


\section{Introduction}

In general, animals show a series of traits and defensive mechanisms to avoid predation and stay alive. Organisms reduce the probability of being predated by using many adaptations or behavioral strategies, which may present specific behaviors (displays) that can discourage a predator's attack (Greene 1988). Predation pressure is a fundamental selective force for the development of a series of traits that increase prey survival, by limiting the predator ability to detect, recognize, approach, subjugate or consume the prey (Endler 1986, Greene 1988, Lima \& Dill 1990). In general, antipredator mechanisms are an important factor in the evolutionary processes of many animals (e.g., Vermeij 1982, Lima \& Dill 1990). Vertebrates, in particular the Squamata, exhibit extremely diverse antipredator tactics (e.g., Pough et al. 2004, Rocha 1993), making this group an interesting model to examine evolutionary mechanisms to avoid predation (e.g., Greene 1988). In snakes, many defensive displays have been characterized including various ways of intimidating or avoiding aggressors (Greene 1988, Tozetti et al. 2009). Unfortunately, much less information is available on the defensive behavior of lizards compared to snakes. The most reported defensive behavior of lizards in the literature is tail loss (autotomy) and locomotor escape (Greene 1988, Roberts et al. 1998, Rocha-Barbosa et al. 2008). Additionally, some lizards exhibit a peculiar defensive behavior: death-feigning. Death-feigning (thanatosis) is a state of immobility assumed by many animals in response to external stimuli. This behavior has been considered a defense mechanism against predators and is shared by mammals (e.g., Francq 1969), birds (e.g., Sargeant \& Eberhardt 1975), fishes (e.g., Howe 1991), amphibians (e.g., Gargaglioni et al. 2001, Bertoluci et al. 2007), reptiles (e.g., Greene 1988), and insects (e.g., Acheampong \& Mitchell 1997). Death feigning is also known as catalepsy, or tonic immobility. In most cases, animals that exhibit this behavior "play dead" by maintaining a rigid posture or by simulating fully relaxed muscles (e.g. fainting; Greene 1988). Apparently thanatosis is a behavior that rarely occurs spontaneously (Greene 1988). Immobility might discourage sequential attacks, allowing escape, as demonstrated in experiments using invertebrates (Miyatake et al. 2004). While efficiency in this defensive behavior have been poorly tested, its occurrence in several vertebrate groups suggests a favorable evolutionary pressure toward its maintenance (Miyatake et al. 2004). In frogs, for example, the thanatosis was pointed out as an important secondary defense mechanism in Phillomedusa (Sazima 1974). In lizards, death-feigning has been reported for several different families, such as Anelytropsidae (Torres-Cervantes et al. 2004), Crotaphytidae (Gluesing 1983), and Scincidae (Langkilde et al. 2003). Among tropidurid lizards, this behavior has been observed in Eurolophosaurus nanuzae Rodrigues, 1981 (Galdino \& Pereira 2002), E. divaricatus Rodrigues, 1984 (Gomes et al. 2004, Kohlsdorf et al. 2004) previously Tropidurus nanuzae and T. divaricatus (Frost et al. 2001), T. torquatus Wied, 1820 and T. hispidus Spix, 1825 (Bertoluci et al. 2006). Bertoluci et al. (2006) has also reported anecdotal records for several other species in the tropidurid family. Among Liolaemidae, this behavior has been reported only in Liolaemus lutzae Mertens, 1938 (Rocha 1993). This family consists of 229 species (including subspecies) belonging to the genera Ctenoblepharys, Phymaturus, and Liolaemus. The latter comprises most of the species of the family, with 200 species (Pincheira-Donoso et al. 2008a). Considering the great diversity in ecological specializations and morphology, Liolaemus is an important group to study adaptive radiations (Pincheira-Donoso et al. 2008b). The South American Liolaemus lizards occurs in Argentina, Bolivia, Brazil, Chile, Paraguay, Peru, and Uruguay, which represents the widest range of environments occupied by a single lizard genus. The
Liolaemus occipitalis Boulenguer, 1885 is a small sand-dune-lizard associated to coastal habitats and its geographic distribution restricted to Rio Grande do Sul and Santa Catarina States, southern Brazil (Bujes \& Verrastro 2008), and Uruguay (Verrastro et al. 2006). It is primarily an insectivorous reptile that reproduces between September and March (Verrastro \& Krause 1994). Despite being a threatened species (Marques et al. 2002), available data on its natural history and behavior obtained in the field are scarce. In addition, the impact that sand dune habitats have been enduring highlight the importance of ecological studies on species associated to this environment (Seeliger 2003). Here we report observations of the defensive behavior of L. occipitalis in nature and the first record of death-feigning in this species.

\section{Methods}

The data presented in this study was collected between November 2009 and January 2010 in the municipality of Rio Grande, RS, in an area known as Balneário Cassino, southernmost Brazil (32 07' 54.65" - $32^{\circ} 17^{\prime} 35.07^{\prime \prime} \mathrm{S}$ and $52^{\circ} 06^{\prime} 38.80^{\prime \prime}$ - 52 $22^{\circ}$ '53.36" W) located at sea level. The area consists of well preserved wet habitats formed by meadows with a mosaic of dunes, sand dune vegetation and temporary lagoons. The climate is classified as subtemperate (Maluf 2000), with an average annual maximum temperature of $23.3{ }^{\circ} \mathrm{C}$ and average annual minimum temperature of $12.7^{\circ} \mathrm{C}$. The seasons are well defined, with rainfall homogeneously distributed along the year and averaging $1252 \mathrm{~mm}$ between 1931 and1990 (INMET 2010). During field surveys of the regional herpetofauna, we captured 86 individuals of Liolaemus occipitalis using pitfall traps with drift fences (Brasileiro et al. 2005). The lizards remained a maximum of eight hours in buckets containing water and shelter to protect them against the sunlight, minimizing the stress on captured animals. All lizards were handled carefully during measurements (body size and mass), sex determination, and assessment of the reproductive condition of females by palpation (Fitch 1987). While being held, some individuals feigned death (Figure 1). The animals that exhibited this behavior were immediately placed on the ground and observed from two distances, 1 and $7 \mathrm{~m}$, whose order was set at random. In one of the distances, individuals were observed until recovery. The animal was then captured by hand and if death-feigning was observed again, the observation was repeated from a second distance from the lizard. The duration of the behavior was recorded in each observation. Only animals that exhibited this behavior from the two distances from the observers (treatments) were considered. Because this species exhibit intraspecific agonistic interactions (M.B. Santos, personal observation), we only tested individuals that were alone in the traps. This measure was taken to reduce the stress level of lizards prior to manipulation. Each observation was considered a sample. Comparisons between the durations of the behavior from different distances were conducted with a paired Wilcoxon test (Zar 1999). After recording the behavior, lizards were toe-clipped (Waichman 1992) before being released five meters from traps. Recaptured animals were not included in the behavior assessment.

\section{Results and Discussion}

Eighty-six lizards (47 males, 31 females, and 8 juveniles) were captured. The average size of animals was $47.5 \pm 9.3 \mathrm{~mm} \mathrm{SVL}$ (range - females: 37.0 - $66.0 \mathrm{~mm}$; males: 40.0 - $63.0 \mathrm{~mm}$; juveniles: $22.0-30.0 \mathrm{~mm}$ ) and the average body mass was $3.60 \pm 1.6 \mathrm{~g}$ (range females: $1.3-5.3 \mathrm{~g}$; males: $1.8-7.8 \mathrm{~g}$; juvenile: $0.3-0.8 \mathrm{~g}$ ). During handling, 65 lizards $(75.6 \%)$ feigned death, 35 were males, 23 were females and seven were juveniles (Figure 2). This represents $74.5 \%$ of males, $74.2 \%$ of females, and $87.5 \%$ of juveniles. 

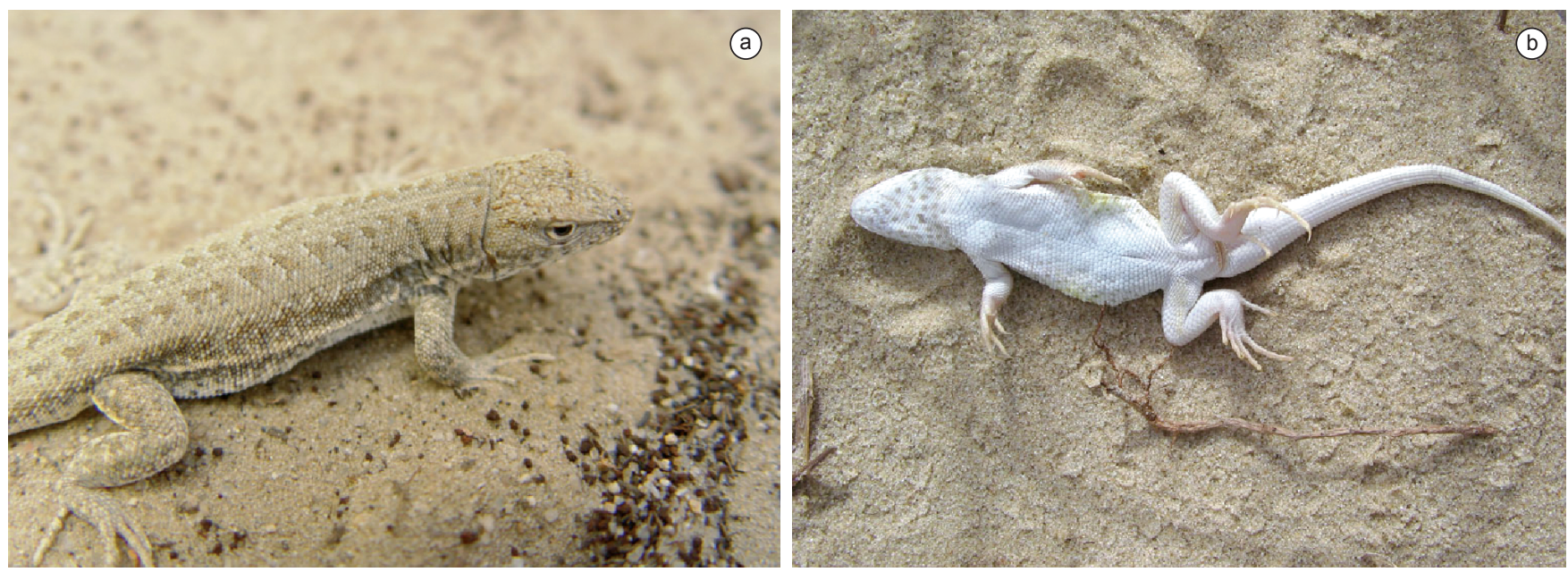

Figure 1. a) general aspect of an individual of Liolaemus occipitalis Boulenguer, 1885; and b) an individual feigning death.

Figura 1. a) aspecto geral de um indivíduo de Liolaemus occipitalis Boulenguer, 1885; e b) indivíduo exibindo o comportamento de tanatose.

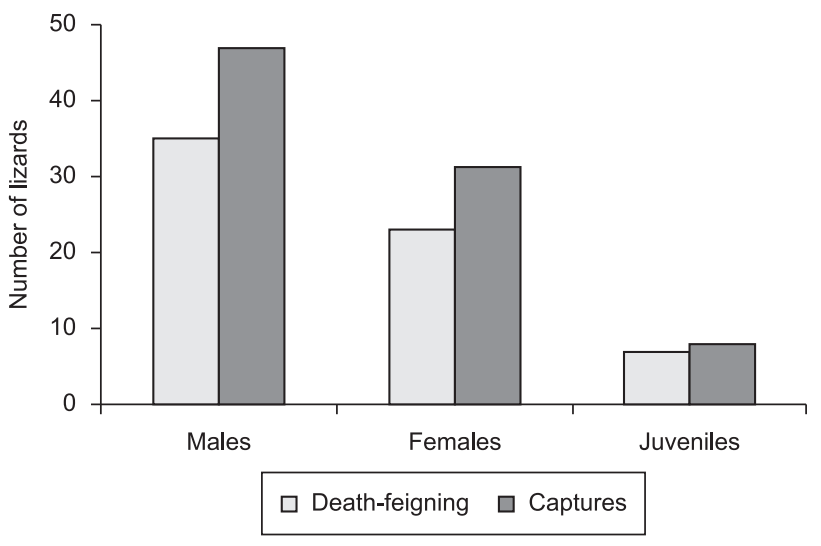

Figure 2. Absolute number of Liolaemus occipitalis lizards captured by pitfall traps with drift fence and number of lizards that feigned death during handling.

Figura 2. Número absoluto de indivíduos de Liolaemus occipitalis capturados em armadilha de interceptação e queda e que apresentaram o comportamento de tanatose durante a manipulação.

The death-feigning behavior observed in our study was similar to that described in Tropidurus species by Bertoluci et al. (2006). During handling, L. occipitalis lizards exhibited very relaxed muscles, remained immobile in the observer's hand, and maintained this posture when placed on the ground (Figure 1). During death-feigning, simultaneous slow and lateral tail movements and intermittent movements of opening and closing the eyes were observed. Some studies show that habitat characteristics confer different probabilities of predation of lizards (Shepard 2007). Although L. occipitalis is associated with open environments like sand dunes, the presence of shrubs, even sparse ones, provides shelter and protection against predators (Bujes \& Verrastro 1998). In addition, the cryptic coloration and the ability of digging burrows are probably its main strategies against predation. Also, L. occipitalis is an ambush forager (M.B. Santos, personal observation), which might decrease the time of exposure to visually-oriented predators. Apparently, when a predator is detected, the main active defense strategy of L. occipitalis is to escape and the capacity of burying (Bujes \& Verrastro 1998). However, the capacity of escape, especially the speed, depends on body temperature as well as reproductive conditions (Shine 1980,
Plummer 1997, Miles et al. 2000). As a result of these constraints, a diversification in defense strategies might increase the probability of survival of individuals. Because thanatosis only occurs if stimulated (e.g. handling), this could indicate that this strategy represents an extreme measure used after a first attack by the predator. Thus, escape and cryptic behavior combined represents ways to avoid perception or capture, while death-feigning might be a strategy used when the lizard has been already captured by the predator. It should be pointed out that the duration of thanatosis was significantly longer $(\mathrm{T}=0.0$; $\mathrm{P}=0.028 ; \mathrm{n}=12$ ) when the observed remained near (average duration $=10.2 \pm 1.99$ minutes; range $=7.2-12.7$ minutes) than when the observed was farther away from lizards (average duration = $2.0 \pm 1.14$ minutes; range $=0.5-3.83$ minutes), suggesting that the animals are capable of evaluating the threat level.

It should be pointed out that during previous studies conducted with other populations of $L$. occipitalis, death-feigning was rarely observed (M.B. Santos, personal observation). The high frequency of records of this behavior in the population of the present study might be associated with a selective process toward this defensive mechanism. Studies on experimental handling demonstrated that the duration of death feigning observed in insects was a result of different selection pressures caused by predation (Prohammer \& Wade 1981). However, in our study, this hypothesis still needs to be further investigated with experimental studies in which the actual predation pressure is quantified, as well as the efficacy of death-feigning to avoid the action of predators.

\section{Acknowledgments}

We are grateful to Col. Augusto Martins for providing transportation to the study area. The study was conducted with laboratory assistance of several biologists, especially Tatiane Penteado Gonçalves and Alexandre Hartmann. We also thank CNPq (process 476661/2008-0) and FAPERGS (process 0902139) for grants received and ICMBio for collecting permits.

\section{References}

ACHEAMPONG, A. \& MITCHELL, B.K. 1997. Quiescence in the Colorado potato beetle, Leptinotarsa decemlineata. Entomol. Exp. Appl. 82(1): 83-89.

BERTOLUCI, J., CASSIMIRO, J. \& RODRIGUES, M.T. 2006. Tropiduridae (tropiduridae lizards). Death-feigning. Herpetol. Rev. 37(4):472-473. 
BERTOLUCI, J., BRASSALOTI, R.A., SAWAKUCHI, H.O., RIBEIRO JR., J.W. \& WOEHL, G. 2007. Defensive behaviour with stiff-legged posture in the Brazilian tree toads Dendrophryniscus brevipollicatus and D. leucomystax (Anura, Bufonidae). Alytes 25(1-2):38-44.

BRASILEIRO, C.A., SAWAYA, R.J., KIEFER, M.C. \&. MARTINS, M. 2005. Amphibians of an open Cerrado fragment in southeastern Brazil. Biota Neotrop. 2(5): http://www.biotaneotropica.org.br/v5n2/pt/ abstract?article+BN00405022005 (último acesso em 10/04/2010.

BUJES, C.S. \& VERRASTRO, L. 1998. Comportamento de Liolaemus occipitalis em cativeiro (Sauria:Tropiduridae). Rev. Bras. Zool. 15(4):915920.

BUJES, C.S. \& VERRASTRO, L. 2008. Microhabitat use by the saxicolous lizard, Liolaemus occipitalis (Squamata, Tropiduridae), in the coastal sand dunes of Rio Grande do Sul, Brazil. Iheringia. Ser. Zool. 98(1):156160.

ENDLER, J.A. 1986. Defense against predators. In Predator-Prey Relationships. Perspectives and approaches from the study of lower vertebrates (M. Feder \& G. Lauder, eds). The Univ. Chicago Press, Chicago, IL, p. 109-134.

FITCH, H.S. 1987. Collecting and life history techniques. In Snakes: ecology and evolutionary biology. (R.A. Seigel, J.T. Collins \& S.S. Novak, eds.). New York: McMillan Publishing Company, p. 143-164.

FRANCQ, E.N. 1969. Behavioral aspects of feigned death in the opossum Didelphis marsupialis. Am. Midl. Nat. 81(2):556-567.

FROST, D.R., RODRIGUES, M.T., GRANT, T. \& TITUS, T.A. 2001 Phylogenetics of the lizard genus Tropidurus (Squamata: Tropiduridae): Direct optimization, descriptive efficiency, and sensitivity analysis of congruence between molecular data and morphology. Mol. Phylogenet. Evol. 21(3): 352-371.

GALDINO, C.A.B. \& PEREIRA, E.G. 2002. Tropidurus nanuzae (NCN). Death feigning. Herpetol. Rev. 33(1):54.

GARGAGLIONI, L.H., PEREIRA, A.S. \& HOFFMANN, A. 2001. Basal midbrain modulation of tonic immobility in the toad Bufo paracnemis. Physiol Behav. 72(3):297-303.

GLUESING, E.A. 1983. Collared lizard predation: the effects of conspicuous morphology and movement. Copeia 1983(3):835-837.

GOMES, F.R., KOHLSDORF, T., NAVAS, C.A. 2004. Death-feigning in Eurolophosaurus divaricatus: temperature and habituation effects. Amphibia-Reptilia. 25(3):321-325.

GREENE, H.W. 1988. Antipredator mechanisms in reptiles. In Biology of the reptilia (C. Gans \& R.B. Huey, eds.). Alan R. Liss, New York, vol.16, p.1-152.

HOWE, J.C. 1991. Field observations of death feigning in the convict tang, Acanthurus triostegus (Linnaeus), with comments on the nocturnal color pattern in juvenile specimens. J. Aquaricult. Aquat. Sci. 6(4):13-15.

INMET 2010. Normais climatológicas. http://www.inmet.gov.br/html/clima. $\mathrm{php?Ink/html/clima/mapas} \mathrm{(accessed} \mathrm{on} \mathrm{August} \mathrm{2010).}$

KOHLSDORF, T., RODRIGUES, M.T. \& NAVAS, C.A. 2004. Eurolophosaurus divaricatus (NCN). Death feigning. Herpetol.1 Rev. 35(4):390-391.

LANGKILDE, T., SCHWARZKOPF, L. \& ALFORD, R. 2003. An ethogram for adult male rainbow skinks, Carlia jarnoldae. Herpetol. J. 13(3):141-148.

LIMA, S.L. \& DILL, L.M. 1990. Behavioral decisions made under the risk of predation: a review and prospectus. Can. J. Zoolog. 68(4):619-640.

MALUF, J.R.T. 2000. Nova classificação climática do estado do Rio Grande do Sul. Rev. Bras. Agromet. 8(1):141-150.

MARQUES, A.A.B., FONTANA, C.S., VÉLEZ, E., BENCKE, G.A., SCHNEIDER, M. \& REIS, R. E. 2002. Lista das espécies da fauna ameaçadas de extinção no Rio Grande do Sul. Publicações avulsas Fundação Zoobotânica, 11, Porto Alegre, FZB/MCT- PUCRS/PANGEA. 52p.

MILES, D.B., SNERVO, B. \& ANTHONY, F.W. 2000. Reproductive burden, locomotor performance, and the cost of reproduction in free ranging lizards. Evolution. 54(4):1386-1395.
MIYATAKE, T., KATAYAMA, K., TAKEDA, Y., NAKASHIMA, A., SUGITA, A. \& MIZUMOTO, M. 2004. Is death-feigning adaptive? Heritable variation in fitness difference of death-feigning behaviour. Proc. R. Soc. B. 271:2293-2296.

PINCHEIRA-DONOSO, D., SCOLARO, J.A. \& SURA, P. 2008a. A monographic catalogue on the systematics and phylogeny of the South American iguanian lizard family Liolaemidae (Squamata, Iguania). Zootaxa. 1800:3-85.

PINCHEIRA-DONOSO, D., HODGSON, D.J. \& TREGENZA, T. 2008b. Comparative evidence for strong phylogenetic inertia in precloacal signaling glands in a species-rich lizard clade. Evol. Ecol. Res. 10:11-28. Zootaxa 1800:1-85.

PLUMMER, M.V. 1997. Speed and endurance of gravid and nongravid green snakes, Opheodrys aestivus. Copeia. 1997:191-194.

POUGH, F.H., ANDREWS, R.H., CADLE, J.E, CRUMP, M.L., SAVITZKY, A.H. \& WELLS, K.D. 2004. Herpetology. 3. ed. Pearson Pretince Hall, Upper Saddle River.

PROHAMMER, L.A. \& WADE, M.J. 1981. Geographic and genetic variation in death-feigning behavior in the flour beetle, Tribolium castaneum. Behav. Genet. 11:395-401.

ROBERTS, T.J., KRAM, R., WEYAND, P.G. \& TAYLOR, C.R. 1998. Energetics of bipedal running I. Metabolic cost of generating force. J. Exp. Biol. 201(19):2745-2751.

ROCHA, C.F. 1993. The set of defense mechanisms in a tropical sand lizard (Liolaemus lutzae) of southeastern Brazil. Rev.Ciênc. Cult. SBPC 45:116-122.

ROCHA-BARBOSA, O., LOGUERCIO, M.F.C., VELLOSO, A.L.R. \& BONATES, A.C.C. 2008. Bipedal locomotion in Tropidurus torquatus (Wied, 1820) and Liolaemus lutzae Mertens, 1938. Braz. J. Biol. 68(3):649-655.

SARGEANT, A.B. \& EBERHARDT, L.E. 1975. Death feigning by ducks in response to predation by red foxes (Vulpes fulva). Am. Midl. Nat. 94:108-119.

SAZIMA, I. 1974. Experimental predation on the leaf-frog Phyllomedusa rohdei by the water snake Liophis miliaris. J. Herpetol. 8(4):376-377.

SEELIGER, U. 2003. Response of southern Brazilian coastal foredunes to natural and human-induced disturbance. J. Coastal. Res. 35:51-55.

SHEPARD, D.B. 2007. Habitat but not body shape affects predator attack frequency on lizard models in the Brazilian cerrado. Herpetologica 63:193-202.

SHINE, R. 1980. "Costs" of reproduction in reptiles. Oecologia 46:92-100.

TORRES-CERVANTES, R.J., HERNANDEZ-IBARRA, X. \& RAMIREZBAUTISTA, A. 2004. Anelytropsis papillosus (Mexican blind lizard). Death feigning and autotomy. Herpetol. Rev. 35(4):384.

TOZetti, A.M., OliveirA, R.B. \& PONTES, G.M.F. 2009. Defensive repertoire of Xenodon dorbignyi (Serpentes, Dipsadidae). Biota Neotrop. 9(3): http://www.biotaneotropica.org.br/v9n3/en/ abstract?article+bn03409032009 (último acesso em 25/02/2010).

VERMEIJ, G.J. 1982. Unsuccessful predation and evolution. Am. Nat. 120:701-720.

VERRASTRO, L. \& KRAUSE, L. 1994. Analysis of growth in a population of Liolaemus occipitalis Boul.1885, from the coastal sand-dunes of Tramandaí, RS, Brazil. (Reptilia-Tropiduridae). Stud. Neotrop. Fauna E. 29:99-111.

VERRASTRO, L., SILVA, C.M. \& SCHOSSLER, M. 2006. A new distribution of Liolaemus occipitalis (sand lizard). Uruguay: Departamento de Rocha. Herpetol. Rev. 37:495.

WAICHMAN, A.V. 1992. An alphanumeric code for toe clipping amphibians and reptiles. Herpetol. Rev. 23(1):19-21.

ZAR, J.H. 1999. Biostatistical analysis. $2^{\text {nd }}$ ed. Prentice-Hall, Upper Saddle River (NJ), 718p. 
